\title{
Antisemitic Anti-Zionism: Muslim Brotherhood, Iran, and Hezbollah
}

As a preacher on Al Jazeera and head of the European Council for Fatwa and Research, Yusuf al-Qaradawi is one of Sunni Islam's most influential intellectuals. Al-Qaradawi has gone beyond denying the Holocaust to presenting it as an example to be followed: according to him, Hitler was the "ultimate punishment" for the Jews, inflicted on them by Allah for their depravity. In the future, he believes, the Muslims must take on the task. In 2009, he stated that, "God willing, the next time this punishment will be inflicted by the hand of the Faithful." 1 The Egyptian Muslim Brotherhood in which Al-Qaradawi has his roots shaped all the later currents of radical Islam, including the Iranian regime and Hezbollah. While these latter are, of course, in some respects in competition with Brotherhood groups and parties, they can also cooperate with them, especially when it comes to fighting Israel and with respect to a shared hostility to the rulers of Saudi Arabia, ${ }^{2}$ considered by some supporters of the Iranian regime to be descendants of Jews.

The prototypical Islamist organization, the Muslim Brotherhood, was founded in 1928, in the same period as the rise of the fascist mass organizations in Europe. It also drew inspiration from the writings of the Iranian Islamists of the nineteenth century. The Nazis actively supported the establishment of the Brotherhood materially and ideologically. After 1945, it became the "biggest antisemitic organization in the world," with around a million members. ${ }^{3}$ The rapid rise in its membership at the beginning of the 1930s-like the support for European fascism and Nazism but in a different religious context-resulted from a massive and delusional projective reaction to the crisis-ridden onslaught of capitalist modernity. This reaction against the ambivalences and emancipatory potential of modernity was also one of the main grounds for the mass support of Khomeini from the 1960s onwards in Iran.

1 J. Cáceres, “'An den Teufel verkauft', Süddeutsche Zeitung, December 22, 2010, https://www. sueddeutsche.de/sport/neuer-sponsor-beim-fc-barcelona-an-den-teufel-verkauft-1. 1039090 - 0\#seite-2.

2 See J. Risen, “A Secret Summit. Iran's Quds Force and the Muslim Brotherhood Considered an Alliance Against Saudi Arabia,” The Intercept, November 18, 2019, https://theintercept.com/ 2019/11/18/iran-muslim-brotherhood-quds-force/.

3 M. Küntzel, Nazis und der Nahe Osten: Wie der islamische Antisemitismus entstand (Leipzig: Hentrich \& Hentrich, 2019), 120.

Ә OpenAccess. (C) 2021 Armin Lange, Kerstin Mayerhofer, Dina Porat, Lawrence H. Schiffmann, published by De Gruyter. (cc)BY-NC-ND This work is licensed under the Creative Commons Attribution-NonCommercialNoDerivatives 4.0 International License. https://doi.org/10.1515/9783110671964-010 
While the political programme of the Muslim Brotherhood was legitimated by reference to the religious texts of Islam, resulting in clear differences from fascism and Nazism in spheres such as sexual morality and gender politics, it closely resembled and still closely resembles the radical right in Europe in crucial politico-economic respects: rejection of parliamentarianism and multi-party democracy, the struggle against liberalism and Marxism, demonization of interest and proclamation of a community of interest between capital and labour, which has to be defended against the allegedly destructive forces of an abstraction identified as Jewish.

In their advocacy of sacrifice, their death cult and their antisemitism, texts such as Industry of Death, issued by the Brotherhood's founder Hassan alBanna in 1938, or Sayyid Qutb's 1950 tract, Our Struggle with the Jews, recall Nazism, despite their Islamic orientation. And these were and are not the pamphlets of isolated cranks but have been and are still being disseminated in millions of copies in some Islamic countries. Before the Islamic Revolution in Iran, Sayyid Qutb's writings were translated into Farsi by Iran's current Supreme Leader, Ali Khamenei, and continue to form one of the central ideological reference points of the Iranian Islamists. ${ }^{4}$

Just like the Nazis, even if less successfully, the Sunni jihadists and Iranian Islamists are concerned not only with the enlistment of a people for the purposes of exploitation and domination but with the formation of a society of martyrs, in which individuals sacrifice themselves for the umma, the community of all Muslims.

Despite all the real and significant differences in historic context, legitimating references, economic and political structures and military capability, the hate objects of the Islamic Jihadists resemble those of Nazism: communism and materialism, liberalism and Western "plutocracy," individualism, emancipation, and Zionism.

After 1946, Hassan al-Banna showered praise on Amin el-Husseini, the rabidly antisemitic Mufti of Jerusalem, who had collaborated with the Nazis and resided in Berlin after 1941. He managed to evade prosecution by the Allies after the Second World War by fleeing to Cairo, where, in 1946, al-Banna, today still a revered figure, declared of him:

4 See Y. Ünal, "Sayyid Qutb in Iran: Translating the Islamist Ideologue in the Islamic Republic," Journal of Islamic and Muslim Studies 1, no. 2 (2016): 35-60. 
What a hero, what a miracle of a man [...] who defied an empire with the help of Hitler and Germany and fought against Zionism. Germany and Hitler are no more, but Amin Al-Husseini will pursue the struggle. ${ }^{5}$

Recently, the German-Egyptian writer Hamed Abdel-Samad has brought the term "Islamic fascism" back into the discussion, ${ }^{6}$ emphasizing the links between Islamism in general and the Muslim Brotherhood in particular with fascism and Nazism, albeit on the basis of a dubious religious exegesis rather than an ideological-critical understanding of antisemitism in which modern Islamic Jew-hatred is decoded as a projective repudiation of a new, ambivalent and potentially emancipatory form of society: as a form of modern anti-modernism. Moreover, the specific quality of the Islamic antisemitism characteristic of the Brotherhood and Iranian regime needs to be emphasized, since "only here do we find the degrading anti-Judaism of early Islam fused with modern conspiracy-theorizing antisemitism."7

Today, use of the term Islamic fascism excites kneejerk reactions, particularly in parts of the Left. However, it is virtually unavoidable when it comes to dealing with authoritarian antisemitic mass movements with a leader cult and martyrdom ideology, that wage permanent campaigns against groups deemed threatening to the unity of the umma, use unrestrained brute force against political opponents, and advocate a "third way" between capitalism and socialism, East and West.

A more serious question is whether the fixation on the term fascism does not tend to underplay the antisemitic dimension, since the centrality of antisemitism in all variants of the Islamist discourse make it far closer to Nazism, despite all the differences in other spheres, than to classical fascism of the Italian variety. This centrality is especially clear in the case of the Islamist ideology of the regime that has ruled Iran since 1979 and its allies such as Hezbollah, which today present one of the main threats to Israel.

\section{The Government of the Gangs and Antisemitism}

Three main points need to be addressed in relation to the Iranian regime's antisemitism: firstly, the traditional Jew-hatred that is especially apparent in, but

5 J. Herf, "Hitlers Dschihad. Nationalsozialistische Rundfunkpropaganda für Nordafrika und den Nahen Osten,” Vierteljahrshefte für Zeitgeschichte 58, no. 2 (2010): 285.

6 H. Abdel-Samad, Der islamische Faschismus: Eine Analyse (Munich: Droemer, 2014).

7 Küntzel, Nazis und der Nahe Osten, 34. 
not confined to its founder, Khomeini, who is still revered by the regime's supporters; secondly, the denial and relativization of the Holocaust; thirdly, the explicit threats to destroy Israel and the regional policies that result from it. While all these aspects are present at all stages of the history of the Islamic Republic, at certain times particular ones have come to the forefront.

Explicit Jew-hatred is especially marked in Khomeini's pre-revolutionary writings, but even after 1979 it continually breaks through and today determines, alongside traditional Islamic laws, discriminatory practices against Iran's Jewish minority. Verbal attacks on Israel and the support for anti-Israel terrorist groups have been a constant feature of the Iranian regime's ideology and practice and have been voiced and translated into action since 1979 by all factions of the regime. Hatred of the Jewish state is one of the core elements of the Islamist ideology and is by no means only a "means to an end." 8 The heyday of Holocaust denial came during the presidency of Ahmadinejad, who placed it at the centre of his policy and rhetoric, but both his predecessors, Ali Akbar Hashemi Rafsanjani and Mohammed Khatami, were also Holocaust deniers, as is the current Supreme Leader, Ali Khamenei. Since 2013, the current president and his foreign minister, Mohammad Javad Zarif, have toned down the Holocaust denial somewhat, but even under Hassan Rouhani, Iranian official bodies have been involved in Holocaust denial events.

The relativization of Nazi crimes has been promoted by the Rouhani administration itself-an example being Zarif's statement that, "we condemn the Nazis' massacre of the Jews. And we also condemn the massacres of Palestinians committed by the Zionists." ${ }^{9}$ Here he not only downgrades the Shoah to a massacre but also declares the Israelis to be the Nazis of today. Many international observers chose to interpret this statement as a clear break with Holocaust denial. In fact, it represents a modernization of antisemitism by adapting it to international anti-Israel custom and practice.

Finally, it must be remembered that the official line on such matters is set not by the president or foreign minister but by the clerical supreme leader whose powers include the right of appointment to over one hundred leading positions in the political, judicial, administrative, military, media, and religious in-

8 G. Schweizer, Iran verstehen: Geschichte, Gesellschaft und Religion (Stuttgart: Klett-Cotta, 2017), 613.

9 “Irans Außenminister verurteilt 'Massaker an Juden'," Der Standard, September 6, 2013, https://www.derstandard.at/story/1378248269034/ashton-trifft-iranischen-aussenminister-endeseptember. 
stitutions. ${ }^{10}$ "Holocaust denial is the official position of Supreme Leader Ali Khamenei and no Iranian official can do anything against it."11

The Iranian regime was quick to condemn the clearly antisemitic attack by a competing Islamist faction on $9 / 11,{ }^{12}$ despite the instances of technical cooperation with Al Qaeda. ${ }^{13}$ This reinforced the already evident tendency of the Western media and experts to downplay and relativize the antisemitic and state-terrorist character of the Iranian regime. ${ }^{14}$

Then, a few years later, during the Presidency of Mahmud Ahmadinejad after 2005, the strident rhetoric of this former Revolutionary Guards officer brought the regime's Holocaust denial and threats to annihilate Israel to the attention of a wider global public. However, both before, during, and after that presidency, the Iranian regime of Ayatollahs and Revolutionary Guards has throughout remained a religiously legitimated dictatorship characterized by an interplay of state and "revolutionary" institutions, with an ideology that is both antisemitic and anti-Western and state-terrorist and martyrdom-orientated.

What distinguishes the Iranian regime from other despotisms conditioned by Islam and makes it especially dangerous is the combination of a revolutionaryactivist Islamism centered on belief in the Mahdi, the state-driven effort to obtain the technology for weapons of mass destruction and a radical anti-Zionism shared by all currents within the regime. The Mahdi is the hidden Twelfth Shiite Imam who, it is believed, will one day return. Under the Iranian Constitution, it is he, rather than the Supreme Leader, who is the head of state in Iran. ${ }^{15}$ Vilayat-e Faqih, the "guardianship of the Islamic Jurists," is intended, through puritanical terror within and the export of the Islamic revolution abroad, to pave the way for his return. The regime that has ruled Iran since 1979 openly proclaims its religious-ideological goal of world rule. Proving the existence of this claim does not require sophisticated critical techniques. A brief look at the explicit content

10 See M. Boroujerdi and K. Rahimkhani, Postrevolutionary Iran: A Political Handbook (Syracuse: Syracuse University Press, 2018), 46-49.

11 M. Mohammadi, Iranian Holocaust Cartoon Competitions and Exhibitions: Goals, Sponsors, and Themes (Washington: United States Holocaust Memorial Museum, 2016), 12.

12 H. Hartenstein, Deutsche Außenpolitik gegenüber Amerika nach 9/11: Eine kontrafaktische Außenpolitikanalyse (Wiesbaden: VS Springer, 2015), 95.

13 J. I. Lieberman, “Remember Iran's Role in 9/11," Wall Street Journal, September 7, 2016, https://www.wsj.com/articles/remember-irans-role-in-9-11-1473290470.

14 See S. Grigat, "Delegitimizing Israel in Germany and Austria: Past Politics, the Iranian Threat, and Post-national Anti-Zionism," in Deciphering the New Antisemitism, ed. A. H. Rosenfeld (Bloomington: Indiana University Press, 2015), 463-68.

15 See Y. Özuguz, ed., Verfassung der Islamischen Republik Iran: Erläuterte Übersetzung (Bremen: m-haditec, 2007), 5. 
of the writings of the regime's founder, Ayatollah Ruhollah Khomeini, is quite enough. ${ }^{16}$ Moreover, Ali Khamenei, who has described Israel as a "cancerous tumor that should be cut and will be cut," ${ }^{17}$ has also made clear statements in this respect. ${ }^{18}$

The antisemitic and conspiracy-theorizing worldview and the threats of destruction against Israel, shared by all factions of the regime, play a decisive and indeed necessary role in integrating the hostile gangs of the Iranian regime, and the factional fight is not only over who is to get the biggest share of the pie but also over who can best advance the program of eliminatory anti-Zionism. In the original and for a long time operational conception of the Islamic Republic, the supreme leader ruled over the factions and mediated between them. The "Prince of the Believers"-as one of the many titles held by the leader describes himembodies the awareness that, as Khomeini once put it, the regime needs two wings in order to achieve its goals and would be in danger of falling if one of them were simply to be cut off.

This conception was called into question by Khamenei's clear and early support for Ahmadinejad during the 2009 electoral farce. Since Rouhani's election in 2013, it has once again become operational. One expression of this restoration has been the composition of Rouhani's first government. In choosing his ministers, Rouhani took into account the wishes of almost all the factions to create a kind of grand coalition in order to broaden the base of the regime and to strengthen it for the prospective annihilation effort. Admittedly, supporters of Ahmadinejad and his longstanding spiritual mentor and political promoter Ayatollah Mesbah-Yazdi, who has declared that "the Jews are the most corrupt in the world, [...] the most seditious group among all human beings and they will not leave Muslims alone until they destroy Islam,"19 were not represented in Rouhani's first cabinet. However, the fact that Khamenei has appointed Ahmadinejad a member of the influential Expediency Council shows that even this faction,

16 See R. Chomeini, "Reden des Ayatollah Chomeini und Staatspräsidenten Bani Sadr," in Teheran: Eine Revolution wird hingerichtet: Dokumente und Reportagen aus DIE ZEIT, ed. M. Naumann and J. Joffe (Hamburg: Heyne, 1980), 242.

17 “Iranian MP Lauds Hezbollah's Anti-Israel Stance,” Fars News, May 20, 2012, available at https://english.khabaronline.ir/news/185076/Senior-Iranian-MP-Lauds-Hezbollah-s-Anti-IsraelStance.

18 See A. Khamenei, "Grundzüge der islamischen Ideologie dargestellt in zehn Punkten," in Der islamische Fundamentalismus: Grundzüge der islamischen Ideologie im Iran, ed. M. Djassemi (Sylt: Djassemi 2001), 17.

19 Quoted by M. Litvak, “Anti-Semitism in Iran: Continuities and Changes,” issued 2010, accessed March 23, 2020, https://haitiholocaustsurvivors.wordpress.com/anti-semitism/yale-antisemitism-conference-papers/anti-semitism-in-iran-continuities-and-changes-by-meir-litvak-2/. 
which stands for an especially radical interpretation of the Mahdi doctrine, continues to play a role. This still holds true after Ahmadinejad was disqualified from the presidential race in 2017 by the Guardian Council. In October 2019, during the second term of President Rouhani, Iranian cleric Ebad Mohammadtabar declared, "God willing, when the Hidden Imam arrives, all us Muslims will, under his leadership, confront the biggest enemy of Islam-the Jews. According to a Quranic verse, the Jews are the greatest enemy of Islam."20

The struggle for official positions and influence between the spiritual, political and military leaderships, the Revolutionary Guards, secret services, and economic elites, and the Larijani brothers, the Khamenei circle and the Rafsanjani clan has calmed down a bit under Rouhani. Since 2013, the various factions must pay somewhat more heed to the overall interests of the regime. However, the interest groups have not disappeared and further such conflicts are inevitable, particularly in relation to efforts to contain the power of the Revolutionary Guards.

Khamenei himself was clearly determined to reign in the Pasdaran's power somewhat, following speculation during Ahmadinejad's term of office about whether the Guards, who had been extending their control over ever-widening spheres of economic and political life, really needed the clergy anymore and whether the theocracy might turn into an open military dictatorship. As a result, there were only three Pasdaran ministers in Rouhani's first government whereas over half of the members of Ahmadinejad's first cabinet were recruited from either the Revolutionary Guards or Basiji. However, this shift has nothing to do with some kind of wind of moderation. It represents merely a shift between power centres, in this case toward the traditional security apparatus, which is in competition with the Pasdaran, and in particular in favour of the VEVAK security service, which was more strongly represented in Rouhani's first government than in any since $1979 .^{21}$

The Iranian regime's aggressive foreign policy, which is characterized simultaneously by pragmatism and a mania for annihilation, corresponds domestically with a social form of organization that is characterized by the rule of competing gangs or "rackets." Drawing on Max Horkheimer's theory of a racket and Franz Neumann's study Behemoth, Gerhard Scheit analyzed the Islamic Republic

20 "Iranian Cleric Ebad Mohammadtabar: When the Hidden Imam Arrives, The Whole World Will Convert to Islam or Die; We Will Confront, Defeat the Jews, Zionism,” MEMRI TV, Clip no. 7517, issued October 7, 2019, accessed August 07, 2020, https://www.memri.org/tv/iraniancleric-mohammadtabar-hidden-imam-jews-world-convert-defeat-confront-zionism.

21 See A. Alfoneh, “President Rouhani’s Cabinet: MOIS vs. IRGC?” FDD Policy Brief, August 7, 2013, http://www.defenddemocracy.org/media-hit/president-rouhanis-cabinet-mois-vs-irgc/. 
as a "non-state." According to his analysis, the Islamist revolution of 1979 represents

the opposite of the bourgeois revolution, which triumphed in France. Both revolutions lifted the state's monopoly on the use of force and replaced it with the power of terrorist groups. However, in one case, the terror results in the rule of law that is guaranteed for the sake of capital's realization by a new monopoly on violence. And in the other case, terror continues undiminished in the different forms of Sharia and sees itself shielded by the name of Allah and oil revenues. ${ }^{22}$

Since Khomeini's accession, the Iranian regime has been characterized by a rivalry of rackets hostile to each other while the supreme religious leader reigns above all. In this way, the whole Iranian constitution cannot be understood as a form of bourgeois law:

The complex structure of the constitution is merely there to provide room for the disparate activities of these rackets, who declaredly prefer the state of emergency. ${ }^{23}$

Since 1979, parallel to the state's organs, additional institutions have been formed in Iran. The influence of the regular courts of justice is restricted through the existence of numerous special courts. Beyond those military tribunals that are common in other countries, there exist so-called "Revolutionary Courts," the "Court for the Justice of Bureaucracy," the "Special Court for the Clergy," and "Press Courts." Besides the national army, the Pasdaran has been established as an alternative revolutionary military force, which today is one of the most influential and probably the most dangerous racket within the regime's power structure. The Revolutionary Guards not only represent the regime's military elite unit but also one of the most important economic conglomerates in Iran, which provides its members with economic and social gains. For several years now, the Pasdaran have used their military power to gain control of crucial branches of Iran's economy, particularly in the realm of foreign trade.

Similar to German National Socialism but in a different way, the Islamic "non-state" of Iran is capitalist and anti-capitalist at the same time:

Its position on ownership of the means of production is different in the respect that in the form of an industrialized mode of production this kind of ownership only exists to a min-

22 G. Scheit, "Der neue Vernichtungswahn und seine internationalen Voraussetzungen: Wodurch sich Ahmadinejads Islamische Republik von Hitlerdeutschland unterscheidet," in Der Iran: Analyse einer islamischen Diktatur und ihrer europäischen Förderer, ed. S. Grigat and S. D. Hartmann (Innsbruck: Studienverlag, 2008), 60.

23 Scheit, "Der neue Vernichtungswahn," 63. 
imal extent. Universal law and contract have disappeared here as well, replaced by the rackets' arbitrary course of actions. ${ }^{24}$

A central difference to National Socialism, however, is its position on labour. The affiliation with the Islamist collective, different from Nazi Germany, has almost nothing to do with labour as a commodity:

In such a collective, even somebody, who does not have any prospect for a job, can feel useful and not superfluous, even when he does not expect the umma to provide him with one. Everything beyond the racket system that threatens and exposes the individual to superfluousness, the individual projects on a total enemy, the Gegen-Volk ("counter-nation"). ${ }^{25}$

These projections culminate in a suicidal desire for annihilation that concentrates on the State of Israel, that includes self-sacrifice, and that is virtually invoked by the Iranian Islamists' ideology of martyrdom.

\section{Traditional Antisemitism in Iran}

In the latter part of the 1930s, the future revolutionary leader Khomeini was a regular listener to the National Socialist shortwave radio station, Radio Zeesen, which disseminated antisemitic Nazi propaganda in the Middle East. ${ }^{26}$ This does not mean that Khomeini identified totally with Hitler's ideology, about which he is said sometimes to have made disparaging remarks. ${ }^{27}$ Other religious notables, such as Ayatollah Abu al-Qasim Kashani, among whose pupils Khomeini must be reckoned, and who in the 1940s was interned in Iran because of his "pro-fascist" attitude, ${ }^{28}$ however, took an explicitly positive stance toward Nazism. In relation to antisemitism, the current Iranian regime is a classic example of the continued impact of Nazism after its military defeat.

Khomeini's ideology was not directed solely against the Israeli state, but, particularly pre-1979, was open about its antagonism to the Jews. In this respect, the future revolutionary leader could draw on the tradition of nineteenth-century

24 Scheit, "Der neue Vernichtungswahn," 68.

25 Ibid., 70.

26 See Küntzel, Nazis und der Nahe Osten, 108.

27 D. Motadel, Für Prophet und Führer: Die Islamische Welt und das Dritte Reich (Stuttgart: KlettCotta, 2017), 136.

28 H.-G. Ebert, H. Fürtig, and H.-G. Müller, Die islamische Republik Iran: Historische Herkunftökonomische Grundlagen-staatsrechtlich Struktur (Berlin: Akademie-Verlag, 1987), 42. 
Persian-Islamic antisemitism. ${ }^{29}$ On several occasions, Khomeini attacked his main political target, Shah Mohammad Reza Pahlavi, as a "Jew" who took his orders from Israel. ${ }^{30}$ The linkage of his fantasies about a "Jewish world-state" that had to be fought, through which he projected his own megalomania onto its prospective Jewish victims, with traditional anti-Jewish attitudes, is a classic example of the fusion of Islamic anti-Judaism and modern antisemitism that characterizes Islamic antisemitism. ${ }^{31}$

The continuing presence of Jewish communities in Iran is often used to call into question the antisemitic character of the regime. It is indeed true that at present Jews in Iran are not persecuted to the same extent as other religious minorities such as the Baha'i that are not recognized as "religions of the book." However, this argument overlooks the fact that Iran's Jews do not enjoy equal civil rights. The Jewish minority faces systematic discrimination and is obliged constantly to distance itself from Israel. Even authors who otherwise downplay Khomeini's explicitly anti-Jewish statements as "polemic" admit that Jews are considered dhimmis, who are subject to many special rules and restrictions and have to accept Islamic domination..$^{32}$ Jews-like most of the other "recognized" minorities-cannot be, for example, ministers, judges, or teachers in regular schools. ${ }^{33}$ All the recognized minorities are subject to discriminatory rules, for example, regarding inheritance, giving evidence in court, and in the operation of the "blood money" system-the financial compensation paid to the family of someone who has been killed or to the victim who has been injured through negligence-which discriminates between Muslims and non-Muslims and between men and women. ${ }^{34}$ In the circumstances, it is not surprising that about

29 See R. Wistrich, A Lethal Obsession: Anti-Semitism from Antiquity to the Global Jihad (New York: Random House, 2010), 830 -37, and N. Weinstock, Der zerrissene Faden: Wie die arabische Welt ihre Juden verlor: 1947-1967 (Freiburg: ça ira, 2019), 52-70.

30 M. Küntzel, “Tehran's Efforts to Mobilize Antisemitism: The Global Impact,” in Deciphering the New Antisemitism, ed. A. H. Rosenfeld (Bloomington: Indiana University Press, 2015), 509. 31 See Küntzel, Nazis und der Nahe Osten, 108.

32 K. Amirpur, "Licht und Schatten. Antisemitismus im Iran," in Neuer Antisemitismus? Fortsetzung einer globalen Debatte, ed. C. Heilbronn, D. Rabinovici, and N. Sznaider (Frankfurt/Main: Suhrkamp, 2019), 229.

33 See H. Fürtig, Großmacht Iran: Der Gottesstaat wird Global Player (Cologne: Quadriga, 2016), 157.

34 See W. Posch, “Juden im Iran: Anmerkungen zu einem antizionistischen Brief an Mahmoud Ahmadinejad: Teil I,” David: Jüdische Kulturzeitschrift 83 (2010): 30. 
90 percent of the estimated 100-150,000 Jews who lived in the country before the Islamic Revolution of 1979 have since departed..$^{35}$

Despite the fact that, since the revolution, Khomeini, Khamenei, and other leading figures in the regime have publicly stated on several occasions that their policy and ideology is not directed against Jews, as long as they distance themselves from Zionism and accept Islamic rule, there have also been explicitly anti-Jewish statements from by no means marginal figures that pay no heed to this rhetorical distinction. It is common to find the terms Jew and Zionist or Jewry and Zionism used interchangeably in Iranian official propaganda. ${ }^{36}$

\section{Holocaust Denial Competitions, Conferences, and Films}

The first international competition for "Holocaust cartoons" took place in 2005 shortly after Ahmadinejad became President. The competition, in which "artists" from sixty-three countries took part, was organized by the Hamshahri Institute, which produces the popular magazine of the same name on behalf of the Tehran city authorities. A selection from the almost 1,200 entries went on public display in August 2006.

In December 2006, under the title, "Review of the Holocaust: Global Vision," the most representative Holocaust denial conference to date took place in Iran, organized by the Institute for Political and International Studies, which is attached to the Iranian Foreign Ministry. It was opened by the Iranian Foreign Minister Manouchehr Mottaki, and President Ahmadinejad attended the closing ceremony.

The event brought together the Who's Who of the international Holocaust denial scene. Among those present were the former head of the Ku Klux Klan, David Duke, Bradley Smith from the "Committee for Open Debate on the Holocaust," the German-Australian right-wing extremist Frederick Toeben, Georges Theil and Robert Faurisson from France, and Herbert Schaller and Wolfgang Fröhlich from Austria. In the years following this conference, the Iranian official

35 See R. Hakakian, "Juden im Iran und die iranische Linke. Persönliche Reflexionen, die notgedrungen politisch sind," in Iran-Israel-Deutschland: Antisemitismus, Außenhandel und Atomprogramm, ed. S. Grigat (Berlin: Hentrich \& Hentrich, 2017), 149.

36 See R. Jaspal, “Delegitimizing Jews and Israel in Iran's International Holocaust Cartoon Contest,” Journal of Modern Jewish Studies 13, no. 2 (2014): 168. 
media played a crucial role in the discussions among and networking within the international Holocaust denial movement. ${ }^{37}$

In 2012 the Iranian regime stepped up its antisemitic agitation when, on April 19, the Israeli day of commemoration of the Shoah, the state broadcaster showed ten animated films that denied the Holocaust in a form otherwise found only among declared old and neo-Nazis. All the animations are based on the book Holocartoons, illustrated by Maziar Bijani and written by Omid Mehdinejad, which was presented by the Iranian Minister of Education, Alireza Ali Ahmadi, in 2008 and was in subsequent years globally disseminated over the internet in several languages. To get an impression of the nauseating character of this explicitly antisemitic effort, it is sufficient to describe the opening scene, which appears in all ten of the films:

We see a Nazi-recognizable from the swastika on his armband-holding a large spray can with "gas" written on it. He activates it. As soon as the screen is totally obscured by the gas, a hook-nosed worm, giggling loudly and marked as Jewish by a kippah, appears and eagerly sucks in the Nazi gas with relish. Finally, he loudly belches out two little clouds of gas that form the word "Holocaust."

The episodes that follow this introduction are on the same level:

One of the films concerns a strange steel contraption displaying the words "gas chamber." The same ten Jews enter from the front and exit from the back of the chamber, while a meter counts the number of through-passages and at the number "six million" rings loudly. Then the ten Jews fall laughing hysterically into one another's arms, having perfectly simulated the murder of six million, although not a single one has died..$^{38}$

Matthias Küntzel notes that these films reveal the global significance of the Iranian regime's Holocaust denial: the use of animation in itself indicates that they are aimed at a global audience. Whatever speech and text there is, is in English. And indeed these pieces were disseminated worldwide, including on YouTube.

In 2014-after Rouhani had become President-the Iranian regime once again provided a platform in Tehran for the international community of conspiracy theorists and antisemites with the "2nd New Horizon Conference of Independent Thinkers." This time, alongside the traditional Holocaust deniers, the

37 H. Schiedel, "Heiliger Hass: Zur rechtsextrem-iranischen Freundschaft," in Iran im Weltsystem: Bündnisse des Regimes und Perspektiven der Freiheitsbewegung, ed. S. Grigat and S. D. Hartmann (Innsbruck: Studienverlag, 2010), 168.

38 M. Küntzel, “Iranische Holocaust-Leugnung und das Internet," Tribüne: Zeitschrift zum Verständnis des Judentums 202, no. 51 (2012): 151. 
bulk of the guests were "9/11 Truthers." The left-liberal Israeli daily Haaretz has described the New Horizon conferences as networking meetings for

Iranian Revolutionary Guards, Russian imperialists, Ukrainian fascists, Chinese spies, Qaddafi devotees, Corbyn fans, Assad apologists, neo-Nazis, Trump devotees, French Holocaust deniers, Western anti-war feminists, African American separatists, Venezuelan socialists and anti-Semites of every conceivable form and type. ${ }^{39}$

In 2015, the second international Holocaust cartoons competition took place under the auspices of the Iran House of Cartoon and the Sarcheshmeh Cultural Complex with participants from over fifty countries. In May 2016 a selection of cartoons went on show at the 11th International Cartoon Biennial and in the Palestine Contemporary Art Museum in Tehran.

In the West, Foreign Minister Zarif claimed that such events were organized by bodies without ties to the state. According to Majid Mohammadi, however, there is no doubt about the responsibility of Rouhani's government for the Holocaust cartoon contest and similar events:

The expenses of these activities are totally paid by governmental institutions, whether military, cultural, municipal, or religious. These institutions, their pseudo branches, and seemingly private affiliates [...] may have misleading titles, but they are all organized, financed, and managed under the Supreme Guide's office, his appointed bodies, and the executive branch headed by the President. ${ }^{40}$

On leader.ir, Khamenei's official English-language website, it has continued to be possible, under Rouhani's Presidency, to read about the "myth" of the Holocaust. Moreover, other prominent figures in the regime have repeatedly spoken in the same vein. Thus Rafsanjani declared on Iranian state radio that his personal research had led him to the conclusion that Hitler murdered no more than 20,000 Jews. ${ }^{41}$ The former President, who, until his death in 2017 was Chairman of the influential Expediency Council, stated, during a visit by the Minister-President of Lower Saxony, Stephan Weil, that before the Second World War, the Zionists had destabilized Europe with money and media. Germany had wished to take re-

39 A. Reid Ross, "The anti-Semitism Fest Where Russian Spies, Code Pink, David Duke and the Nation of Islam Make Friends and Influence People,” Haaretz, March 14, 2019, https://www. haaretz.com/world-news/.premium-russia-s-role-in-an-anti-semitism-fest-for-fascists-feministsspies-and-neo-nazi-1.7003563.

40 Mohammadi, Iranian Holocaust Cartoon Competitions, 4.

41 Anti Defamation League, Holocaust Denial in the Middle East: The Latest Anti-Israel Propaganda Theme (New York: ADL, 2001), 8. 
venge and "send these people to Palestine," leading to the establishment of the State of Israel. In contrast to his earlier statements, in this case Rafsanjani was ready to admit to at least the possibility that six million Jews might have died in the war. However, according to him, this was nothing in comparison with his delusional claim of twenty million deaths and eight million refugees after the foundation of Israel. ${ }^{42}$ His successor, Khatami, meanwhile, who to this day is often presented as the model of a "reformist Islamist," became one of the most passionate defenders of the French Holocaust denier, Roger Garaudy and arranged for him to have an audience with Khamenei. ${ }^{43}$ At the end of 2019, Khamenei on Twitter praised Garaudy’s "bravery and tirelessness." 44

In an interview on CNN in 2013, when asked a direct question about the Holocaust, Rouhani answered that he was a politician and not a historian and could not therefore say anything about the "dimensions of historical events." In May 2019, Mostafa Pourmohammadi, Interior Minister under Ahmadinejad, then Justice Minister in Rouhani's first cabinet and now an advisor to the Head of the Iranian judiciary, aggressively challenged the reality of the "so-called Holocaust," declaring, that, "if we are fighting the Jews-Zionism-then we are fighting the contemporary invasive civilization of arrogance." ${ }^{45}$

Majid Mohammadi succinctly summarizes the different approaches to Holocaust denial of the Iranian regime's various factions-which differ not about the basic aims of the Islamic Republic but how to achieve them:

The only difference between the reformists [...] and nonreformists [...] is their tactics: reformists believe that denying the Holocaust is not a priority [...], while the nonreformists believe that hatred against Israel and Jews will increase the Islamic Republic's influence in the region. They believe that exhibitions of Holocaust cartoons help the Islamic Republic to promote its objectives and strategies to be a force in global issues. ${ }^{46}$

42 A. Will, "Iran-Besuch von Stephan Weil. Herzlicher Empfang mit abruptem Ende," NWZ Online, April 18, 2016, http://mobil.nwzonline.de/politik/niedersachsen/herzlicher-empfang-mitabruptem-ende_a_6,1,2390575300.html.

43 D. Menashri, Post-Revolutionary Politics in Iran: Religion, Society and Power (New York: Routledge, 2001), 279.

44 Sayyid Ali Khamenei (@khamenei_ir), “Bravery and tirelessness of Roger \#Garaudy in the work he initiated is praiseworthy,” Twitter, December 16, 2019, https://twitter.com/khamenei_ ir/status/1206615232451403777.

45 "Kerman Friday Sermon By Former Iranian Minister Mostafa Pourmohammadi: Narrative Of 'So-Called Holocaust' Should Be Researched; The Jews, Zionism Constitute An Invasive Civilization Of Arrogance,” MEMRI, Special Dispatch no. 8253, August 29, 2019, accessed August 7, 2020, https://www.memri.org/reports/kerman-friday-sermon-former-iranian-minister-mostafa-pourmo hammadi-narrative-so-called.

46 Mohammadi, Holocaust, 13. 


\section{Threats to Destroy Israel}

The purpose of the Iranian regime's Holocaust denial and relativization is, firstly, the retrospective delegitimation of the foundation of Israel and, secondly, the prospective legitimation of its destruction. In Iran, the relativization and denial of Nazi crimes serve the regime's eliminatory anti-Zionism. ${ }^{47}$

As regards the conspiracy-theorizing and projective worldview, Holocaust denial and relativization, and the Iranian regime's threats to destroy Israel, nothing substantial has changed under Rouhani. In early 2018, during his second term, the Iranian regime issued an invitation to the "First International Hourglass Festival," whose website israelhourglass.com attacks the "fake regime" named Israel. The Festival's symbol was a Star of David dissolving through an hourglass. The Festival organizer, Hossein Amir-Abdollahian, is an aide to the President of the Iranian pseudo-Parliament, Ali Larijani, and General Secretary of the International Conference in Support of the Palestinian Intifada. He served as a Deputy Foreign Minister under both Ahmadinejad and Rouhani.

For several months, submissions were accepted that illustrated the hopedfor end of Israel in the next twenty-five years and the malicious, "bestial" and "inhuman" character of Zionism and its supporters. The motto of the Festival refers to speeches by Khamenei from 2015 and 2016 in which he proclaimed that the "Zionist regime" would be wiped out by 2040 at the latest. ${ }^{48}$ In 2017 the ruling Ayatollahs had a large digital clock erected in Tehran that is counting down the days until the final victory over the Jewish state.

\section{Hezbollah's Antisemitism}

All factions of the regime are also at one when it comes to supporting the antisemitic terrorist organizations on Israel's borders. At the beginning of 2019, Foreign Minister Zarif, considered a "moderate" in Europe, met with Hezbollah, Hamas, and the Islamic Jihad Movement in Palestine in Beirut to discuss future common

47 Abundant quotations by leading representatives and religious figures of the Iranian regime regarding the destruction of Israel and Holocaust denial can be found in S. Grigat, "The Fight against Antisemitism and the Iranian Regime: Challenges and Contradictions in the Light of Adorno's Categorical Imperative," in Comprehending and Confronting Antisemitism: A Multi-Faceted Approach, ed. A. Lange et al. (Berlin: De Gruyter, 2019), 448-54.

48 A. Khamenei, "There Will Be No such Thing as Israel in 25 Years," issued July 7, 2016, accessed March 23, 2020, http://english.khamenei.ir/news/3969/There-will-be-no-such-thing-as-Is rael-in-25-years-Ayatollah. 
action, while in Tehran Rouhani held a high-profile meeting with Ziyad al-Nakhalah, the new General Secretary of Islamic Jihad. Al-Nakhalah has significantly stepped up the Islamic Jihad's cooperation with Tehran in comparison with his predecessor, Ramadan Shalah, so that it has overtaken Hamas as Iran's main ally in Gaza. ${ }^{49}$

The alliance with the Lebanese terrorist militia Hezbollah has also been maintained under Rouhani, gaining crucial importance in relation to the war in Syria. Moreover, support for the Houthi rebels in Yemen has also been increased in recent years. The Houthi rebels have long had close contacts with Hezbollah, and the Pasdaran and has drawn ideologically closer to the Iranian regime since $2015^{50}$ The slogans of Tehran's Yemeni allies leave no doubt as to their ideological priorities: "God is great!"; "Death to the USA!"; "Death to Israel!"; "Curse on the Jews"; and "Victory to Islam."51

In 2015, Qasem Soleimani, whose influence within the Iranian power structure has grown enormously as a consequence of the Pasdaran's involvement in Iraq and Syria, declared that Iran might soon control Jordan in the same way as it now controls Iraq, Syria, and Lebanon. ${ }^{52}$

Until he was killed by the US military in 2020, Soleimani was the Commander of the Pasdaran's Quds Force, which is responsible for extraterritorial interventions. The name of this force-Al-Quds is the Arabic for Jerusalem-indicates the goal of all their efforts. At the end of 2018, Mohammad Reza Naqdi, Deputy Commander of the Pasdaran and Commander of the Basiji militia, announced that Israel "must be destroyed and wiped out" and "Zionists must be annihilated." ${ }^{3}$ Major General Hossein Salami, the commander of Iran's Revolutionary

49 See M. Shehada, "Iran Is Declaring War on Israel-From Gaza," Haaretz, May 29, 2019, https://www.haaretz.com/middle-east-news/.premium-iran-is-declaring-war-on-israel-fromgaza-1.7065348.

50 See E. Karmon, "Yemen's Houthis: New Members of Iran’s Anti-Israeli/Anti-American Axis," issued May 25, accessed March 23, 2020, 2017, https://www.ict.org.il/Article/2017/yemens-hou this-new-members-of-irans-anti-israeli-anti-american-axis.

51 Quoted by A. Taylor, “The History of 'Death to America', Washington Post, February 18, 2015, https://www.washingtonpost.com/news/worldviews/wp/2015/02/18/the-history-of-deathto-america/?utm_term=.0937e5ff77d7.

52 See J. Khoury, “Iranian Commander: Today Iraq and Lebanon, Tomorrow Jordan," Haaretz, March 23, 2015, https://www.haaretz.com/.premium-today-iraq-and-lebanon-tomorrow-jordan-1. 5341518.

53 "IRGC Deputy Commander Mohammed Reza Naqdi: Israel Must Be Wiped Out, Zionists Annihilated; We Can Destroy KSA, U.S. Bases in the Region,” MEMRI TV, Clip no. 6917, issued December 28, 2018, accessed August 7, 2020, https://www.memri.org/tv/irgc-deputy-commanderreza-naqdi-israel-must-annihilated-destroy-saudi-arabia-american-bases. 
Guards, said in September 2019 that destroying Israel has become an "achievable goal" thanks to his country's technological advances: "This sinister regime must be wiped off the map" and "this is no longer a dream [...]. We have managed to obtain the capacity to destroy the imposter Zionist regime." 54

Deeds have matched words so that now Israel faces on its borders not only the Iranian regime's allies but the regime itself. The incursion by an Iranian drone into Israeli airspace in February 2018, represented a dangerous escalation of the situation as did the Iranian rocket attacks on the Golan Heights in May 2018. In particular, Hezbollah's massive military build-up in Lebanon and the Iranian presence in Syria present Israel with huge problems. Hezbollah, Tehran's most important and powerful ally in the region, today possesses over 130,000 rockets aimed exclusively at the Jewish state. How seriously the threat from a Hezbollah armed to the teeth by Tehran is taken in Israel can be seen inter alia from the fact that the liberal daily Haaretz has criticized the right-wing $\mathrm{Ne}$ tanyahu government for not intervening to destroy the Lebanese terrorist militia's arsenal. ${ }^{55}$

The Lebanese Shiite militia has been involved in many attacks such as the bombing of the Jewish community centre in Buenos Aires in 1994 that killed eighty-five people. Its General Secretary, Hassan Nasrallah, echoes Khamenei and Rouhani in calling Israel a "cancerous, tyrannical entity" 56 and has described Zionist Jews in classically dehumanizing antisemitic terms as "the descendants of apes and pigs." ${ }^{57}$ Back in the early 1990s, the movement's longstanding spiritual leader, Muhammad Hussein Fadlallah, declared the "struggle against the Jewish state" as the "continuation of the struggle of the Muslims against the Jews' conspiracy against Islam." 58

54 AFP, “Top Iran general says destroying Israel 'achievable goal', " Al-Monitor, issued September 30, 2019, accessed March 23, 2020, https://www.al-monitor.com/pulse/afp/2019/10/iran-is rael-military-diplomacy.html\#ixzz61B8LVycz.

55 I. Harel, “A War of No Choice for Israel in Lebanon,” Haaretz, February 1, 2018, https://www. haaretz.com/opinion/a-war-of-no-choice-for-israel-in-lebanon-1.5784461.

56 Quoted by E. Webman, "Die Rhetorik der Hisbollah: die Weiterführung eines antisemitischen Diskurses,” Jahrbuch für Antisemitismusforschung 12 (2003): 44.

57 N. Noe, Voice of Hezbollah: The Statements of Sayyed Hassan Nasrallah (London: Verso, 2007), 187.

58 Quoted by H. Meyer, Hamas und Hizbollah: Eine Analyse ihres Politischen Denkens (Zürich: LIT, 2010), 187. Regarding Fadlallah's relationship to Hezbollah, of which he was not officially a member, see J. Sankari, Fadlallah: The Making of a Radical Shi'ite Leader (London: Saqi Books, 2005). 
Nasrallah more or less exalts over the fact that Jews come from all over the world to Israel, where the "axis of resistance" of Iran and Hezbollah can more easily fight them:

the Jews from the entire world will come to occupied Palestine. But this will not be done for their antichrist to rule. God Almighty wanted to save you the trouble of finding them all over the world..$^{59}$

In 1997 he stated in a speech that

If we search the entire globe for a more cowardly, lowly, weak and frail individual in his spirit, mind, ideology, and religion, we will never find anyone like the Jew-and I am not saying the Israeli: we have to know the enemy we are fighting. ${ }^{60}$

\section{According to the Hezbollah TV station Al-Manar:}

Judaism is a project against all humanity. It's about time the world understands this. Those who are fighting Israel are not just defending themselves; they are defending the whole world [...] There is no such thing as Zionism [...] There is only Judaism. ${ }^{61}$

Nasrallah's deputy, Naim Qassem has declared: “The history of Jews has proven that, regardless of the Zionist proposal, they are people who are evil in their ideas." ${ }^{62}$ In the same way as the Iranian regime, Hezbollah denies or relativizes the Holocaust and defends Holocaust deniers such as Roger Garaudy. ${ }^{63}$ In 2000 Al-Manar proclaimed that, "The Jews have invented the fairy tale of the Nazi massacre against the Jews [...]." 64

In 2003 Al-Manar broadcast a twenty-six-part series that, it explained, would show how "Jews do not shrink from committing the worst crimes in order to realize their Jewish dream." ${ }^{65}$ The whole series, in which Jews are accused of responsibility for both the First and Second World Wars, must be seen as a mod-

59 N. Noe, “[CORRECTION to:] PM Netanyahu used a quote from Nasrallah that was likely fabricated,” issued March 3, 2015, accessed March 23, 2020, https://mideastwire.wordpress.com/ 2015/03/03/pm-netanyahu-used-a-quote-from-nasrallah-that-was-likely-fabricated.

60 Noe, Voice of Hezbollah, 171.

61 Quoted by Wistrich, Lethal Obsession, 775.

62 A. Saad-Ghorayeb, Hizbu'llah: Politics and Religion (London/New York: Pluto, 2002), 174. 63 See ibid., $184-85$.

64 G. Ben-Ari, Die Saat des Hasses: Juden und Israel in den arabischen Medien (Holzgerlingen: Hänssler, 2002), 29.

65 Quoted by C. Bruck, “'Hitler war in Ordnung', DIE WELT, November 18, 2003. 
ernized dramatization and illustration of the antisemitic classic, The Protocols of the Elders of Zion.

Remko Leemhuis, Director of the American Jewish Committee in Berlin and today one of Germany's leading experts on Hezbollah, has succinctly summed up the central role of antisemitism for the Lebanese Shiite militia. It is "not only a basic reference point in Hezbollah's ideology, it is its core." An analysis of the movement's antisemitic propaganda shows that the conflict with Israel "again and again serves as the vehicle for the various antisemitic lines of argument." The battle with the Jewish state "is, therefore, only a catalyst that provides imagery that constantly serves to revitalise and update antisemitic ideologemes."66

\section{The Necessity of a New Policy toward Iran}

The Iranian regime is today one of the main promoters of global antisemitism. With its ongoing effort to obtain the technology of mass destruction and its pursuit of the related missile programme, its regional expansion to the borders of Israel, and the massive arming of its equally antisemitic allies such as Hezbollah, it currently presents the main danger to the security of the Jewish state. This is reflected in the official military strategy of the Israeli defence forces. ${ }^{67}$ It is hard to over-estimate the contribution that the fall of the regime of the Ayatollahs and Pasdaran would make to the fight against global antisemitism and for the defence of Israel.

In these circumstances, it is necessary to break a taboo in the European discussion of Iran and envisage as a both realistic and desirable prospect that scenario that the German Social Democratic Foreign Minister, Heiko Maas, can imagine only as a nightmare: ${ }^{68}$ a future for Iran beyond the rule of the Ayatollahs and Revolutionary Guards.

To help bring this about, the EU must abandon its cooperation and appeasement policy toward Tehran. The nuclear agreement of 2015, to which the EU still

66 R. Leemhuis, "Antisemitismus in der arabisch-islamischen Welt unter besonderer Berücksichtigung der schiitisch-libanesischen Hisbollah” (BA thesis, University of Marburg, 2009), $51-52$.

67 N. Fuhrig and K. Kälker, Israel und das Szenario eines Präventivschlags gegen den Iran (Baden-Baden: Nomos, 2017), 12.

68 See AFP, "Heiko Maas warnt vor Versuchen zur Destabilisierung des Iran," Der Tagesspiegel, August 8, 2018, https://www.tagesspiegel.de/politik/bundesaussenminister-heiko-maas-warntvor-versuchen-zur-destabilisierung-des-iran/22892416.html. 
clings, did not lead to the end of the Iranian nuclear and missile programmes but to their institutionalization. The Ayatollahs' missile programme, which is an essential component of its bid for a nuclear weapons capability, was excluded from the agreement. The entire infrastructure of the nuclear programme remains intact: while the nuclear facilities have been modified and subjected to conditions, the structures themselves are still there. The permanent and unrestricted monitoring that supporters of the agreement for a long time considered essential has not happened, especially with respect to the military structures that the International Atomic Energy Agency suspects of having been used for testing nuclear warheads. It is, therefore, not surprising that the regime has been found to have broadly adhered to the agreement. With the expiry of the absolutely inadequate restrictions in a few years' time, the Joint Comprehensive Plan of Action will have paved the way to the bomb, instead of blocking it.

The deal was a gamble on the future. The agreement's supporters hoped to persuade the Iranian regime to moderate its behaviour. Developments over the past few years, however, have been in the opposite direction. The regime has been encouraged by the deal to pursue an extremely aggressive foreign policy financed by the billions that have flowed in as a result of the deal itself.

The seven hundred rockets that were fired at Israel from Gaza in May 2019, once again showed that cooperation with the Iranian regime has not brought about the stability the EU hoped for but fostered war and terror. When Iranian-backed terrorist groups attack Israel, more than merely verbal solidarity is required from Europe. If the commitment to Israel's security is to be more than empty words, then the European countries and above all Germany, as the successor state to National Socialism, must immediately impose stringent sanctions on the Holocaust-denier regime in Tehran that facilitates the attacks of both Hamas and Islamic Jihad on the state of the Shoah's survivors.

However, to this end, the EU must also free itself from the blackmail to which it exposed itself as a result of the negotiations over the Iranian nuclear programme. The idea of moderating the regime through integrating it into international trade has proved totally illusory. A 180-degree turn in German and European policy toward Iran is urgently needed. There must be no more support for the antisemitic regime and full support for the democratic and secular opposition in Iran and in exile.

Stephan Grigat is lecturer of Political Science at the University of Vienna and at the University of Passau, Permanent Fellow at the Moses Mendelssohn Center for European-Jewish Studies (University of Potsdam), Research Fellow at the Herzl Institute for the Study of Zionism (University of Haifa), and Academic Director of the NGO STOP THE BOMB - For a Nuclear Free \& Democratic Iran. He was Visiting Profes- 
sor at the University of Gießen and Moses Mendelssohn Center and Visiting Lecturer at the Hebrew University of Jerusalem.

\section{References}

Abdel-Samad, Hamed. Der islamische Faschismus. Eine Analyse. Munich: Droemer, 2014.

Alfoneh, Ali. "President Rouhani's Cabinet: MOIS vs. IRGC?” FDD Policy Brief, August 7, 2013. http://www.defenddemocracy.org/media-hit/president-rouhanis-cabinet-mois-vs-irgc/.

Amirpur, Katajun. "Licht und Schatten. Antisemitismus im Iran." In Neuer Antisemitismus? Fortsetzung einer globalen Debatte, edited by Christian Heilbronn, Doron Rabinovici, and Nathan Sznaider, 219-51. Frankfurt/Main: Suhrkamp, 2019.

Anti Defamation League. Holocaust Denial in the Middle East: The Latest Anti-Israel Propaganda Theme. New York: ADL, 2001.

Ben-Ari, Gal. Die Saat des Hasses: Juden und Israel in den arabischen Medien. Holzgerlingen: Hänssler, 2002.

Boroujerdi, Merzahd, and Kourosh Rahimkhani. Postrevolutionary Iran: A Political Handbook. Syracuse: Syracuse University Press, 2018.

Bruck, Christine. "“Hitler war in Ordnung'.” DIE WELT, November 18, 2003.

Cáceres, Javier. “'An den Teufel verkauft'." Süddeutsche Zeitung, December 22, 2010. https:// www.sueddeutsche.de/sport/neuer-sponsor-beim-fc-barcelona-an-den-teufel-verkauft-1. 1039090 - 0\#seite- 2 .

Chomeini, Ruhollah. "Reden des Ayatollah Chomeini und Staatspräsidenten Bani Sadr." In Teheran: Eine Revolution wird hingerichtet. Dokumente und Reportagen aus DIE ZEIT, edited by Michael Naumann and Josef Joffe, 210-53. Hamburg: Heyne, 1980.

Ebert, Hans-Georg, Henner Fürtig, and Hans-Georg Müller. Die islamische Republik Iran: Historische Herkunft-ökonomische Grundlagen-staatsrechtlich Struktur. Berlin: Akademie-Verlag, 1987.

Fuhrig, Nico, and Kevin Kälker. Israel und das Szenario eines Präventivschlags gegen den Iran. Baden-Baden: Nomos, 2017.

Fürtig, Henner. Großmacht Iran: Der Gottesstaat wird Global Player. Cologne: Quadriga, 2016.

Grigat, Stephan. "Delegitimizing Israel in Germany and Austria: Past Politics, the Iranian Threat, and Post-national Anti-Zionism." In Deciphering the New Antisemitism, edited by Alvin H. Rosenfeld, 454-81. Bloomington: Indiana University Press, 2015.

Grigat, Stephan. "The Fight against Antisemitism and the Iranian Regime: Challenges and Contradictions in the Light of Adorno's Categorical Imperative." In Comprehending and Confronting Antisemitism: A Multi-Faceted Approach, edited by Armin Lange, Kerstin Mayerhofer, Dina Porat, and Lawrence Schiffman, 441-61. Berlin: De Gruyter, 2019.

Hakakian, Roya. "Juden im Iran und die iranische Linke. Persönliche Reflexionen, die notgedrungen politisch sind." In Iran-Israel-Deutschland: Antisemitismus, Außenhandel und Atomprogramm, edited by Stephan Grigat, 145-58. Berlin: Hentrich \& Hentrich, 2017.

Harel, Israel. "A War of No Choice for Israel in Lebanon.” Haaretz, February 1, 2018. https:// www.haaretz.com/opinion/a-war-of-no-choice-for-israel-in-lebanon-1.5784461.

Hartenstein, Hendrik. Deutsche Außenpolitik gegenüber Amerika nach 9/11: Eine kontrafaktische Außenpolitikanalyse. Wiesbaden: VS Springer, 2015. 
Herf, Jeffrey. "Hitlers Dschihad. Nationalsozialistische Rundfunkpropaganda für Nordafrika und den Nahen Osten." Vierteljahrshefte für Zeitgeschichte 58, no. 2 (2010): 259-86.

Jaspal, Rusi. "Delegitimizing Jews and Israel in Iran's International Holocaust Cartoon Contest." Journal of Modern Jewish Studies 13, no. 2 (2014): 167-89.

Karmon, Ely. "Yemen's Houthis: New Members of Iran's Anti-Israeli/Anti-American Axis." Issued May 25, 2017. Accessed March 23, 2020. https://www.ict.org.il/Article/2017/yem ens-houthis-new-members-of-irans-anti-israeli-anti-american-axis.

Khamenei, Ali. “Grundzüge der islamischen Ideologie dargestellt in zehn Punkten.” In Der islamische Fundamentalismus: Grundzüge der islamischen Ideologie im Iran, edited by Mohammed Djassemi, 15-18. Sylt: Djassemi, 2001.

Khamenei, Ali. "There Will Be No Such Thing as Israel in 25 Years." Issued July 7, 2016. Accessed March 23, 2020. http://english.khamenei.ir/news/3969/There-will-be-no-suchthing-as-Israel-in-25-years-Ayatollah.

Khoury, Jack. "Iranian Commander: Today Iraq and Lebanon, Tomorrow Jordan." Haaretz, March 23, 2015. https://www.haaretz.com/.premium-today-iraq-and-lebanon-tomorrowjordan-1.5341518.

Küntzel, Matthias. "Iranische Holocaust-Leugnung und das Internet." Tribüne: Zeitschrift zum Verständnis des Judentums 202, no. 51 (2012): 151-57.

Küntzel, Matthias. “Tehran's Efforts to Mobilize Antisemitism: The Global Impact.” In Deciphering the New Antisemitism, edited by Alvin H. Rosenfeld, 508-32. Bloomington: Indiana University Press, 2015.

Küntzel, Matthias. Nazis und der Nahe Osten: Wie der islamische Antisemitismus entstand. Leipzig: Hentrich \& Hentrich, 2019.

Leemhuis, Remko. "Antisemitismus in der arabisch-islamischen Welt unter besonderer Berücksichtigung der schiitisch-libanesischen Hisbollah.” BA Thesis, University of Marburg, 2009.

Lieberman, Joseph I. “Remember Iran's Role in 9/11.” Wall Street Journal, September 7, 2016. https://www.wsj.com/articles/remember-irans-role-in-9-11-1473290470.

Litvak, Meir. "Anti-Semitism in Iran: Continuities and Changes." Issued 2010. Accessed March 23, 2020. https://haitiholocaustsurvivors.wordpress.com/anti-semitism/yale-antisemitism-conference-papers/anti-semitism-in-iran-continuities-and-changes-by-meir-lit vak-2/.

MEMRI. “Kerman Friday Sermon By Former Iranian Minister Mostafa Pourmohammadi: Narrative Of 'So-Called Holocaust' Should Be Researched; The Jews, Zionism Constitute An Invasive Civilization Of Arrogance." Special Dispatch No. 8253. Issued August 29, 2019. Accessed August 07, 2020. https://www.memri.org/reports/kerman-friday-sermonformer-iranian-minister-mostafa-pourmohammadi-narrative-so-called.

MEMRI TV. "Iranian Cleric Ebad Mohammadtabar: When the Hidden Imam Arrives, The Whole World Will Convert to Islam or Die; We Will Confront, Defeat the Jews, Zionism." Clip No. 7517. Issued October 7, 2019. Accessed August 07, 2020. https://www.memri.org/tv/ iranian-cleric-mohammadtabar-hidden-imam-jews-world-convert-defeat-confront-zionism.

MEMRI TV. "IRGC Deputy Commander Mohammed Reza Naqdi: Israel Must Be Wiped Out, Zionists Annihilated; We Can Destroy KSA, U.S. Bases in the Region.” Clip No. 6917. Issued December 28, 2018. Accessed August 07, 2020. https://www.memri.org/tv/irgcdeputy-commander-reza-naqdi-israel-must-annihilated-destroy-saudi-arabia-americanbases. 
Menashri, David. Post-Revolutionary Politics in Iran: Religion, Society and Power. New York: Routledge, 2001.

Mohammadi, Majid. Iranian Holocaust Cartoon Competitions and Exhibitions: Goals, Sponsors, and Themes. Washington: United States Holocaust Memorial Museum, 2016.

Motadel, David. Für Prophet und Führer: Die Islamische Welt und das Dritte Reich. Stuttgart: Klett-Cotta, 2017.

Meyer, Henrik. Hamas und Hizbollah: Eine Analyse ihres Politischen Denkens. Zürich: LIT, 2010.

N. N. "Heiko Maas warnt vor Versuchen zur Destabilisierung des Iran." Der Tagesspiegel, August 8, 2018. https://www.tagesspiegel.de/politik/bundesaussenminister-heiko-maaswarnt-vor-versuchen-zur-destabilisierung-des-iran/22892416.html.

N. N. "Iranian MP Lauds Hezbollah's Anti-Israel Stance." Fars News, May 20, 2012. Available at https://english.khabaronline.ir/news/185076/Senior-Iranian-MP-Lauds-Hezbollah-sAnti-Israel-Stance.

N. N. "Irans Außenminister verurteilt 'Massaker an Juden'." Der Standard, September 6, 2013. https://www.derstandard.at/story/1378248269034/ashton-trifft-iranischen-aussen minister-ende-september.

N. N. “Top Iran General Says Destroying Israel 'Achievable Goal'.” Al-Monitor. Issued September 30, 2019. Accessed March 23, 2020. https://www.al-monitor.com/pulse/afp/ 2019/10/iran-israel-military-diplomacy.html\#ixzz61B8LVycz.

Noe, Nicolas. "[CORRECTION to:] PM Netanyahu used a quote from Nasrallah that was likely fabricated." Issued March 3, 2015. Accessed March 23, 2020. https://mideastwire.word press.com/2015/03/03/pm-netanyahu-used-a-quote-from-nasrallah-that-was-likely-fab ricated.

Noe, Nicolas. Voice of Hezbollah: The Statements of Sayyed Hassan Nasrallah. London: Verso, 2007.

Özuguz, Yavuz, ed. Verfassung der Islamischen Republik Iran: Erläuterte Übersetzung. Bremen: m-haditec, 2007.

Posch, Walter. "Juden im Iran. Anmerkungen zu einem antizionistischen Brief an Mahmoud Ahmadinejad. Teil I.” David: Jüdische Kulturzeitschrift 83 (2010): 30-32.

Reid Ross, Alexander. "The anti-Semitism Fest Where Russian Spies, Code Pink, David Duke and the Nation of Islam Make Friends and Influence People." Haaretz, March 14, 2019. https://www.haaretz.com/world-news/.premium-russia-s-role-in-an-anti-semitism-fest-forfascists-feminists-spies-and-neo-nazi-1.7003563.

Risen, James. “A Secret Summit. Iran's Quds Force and the Muslim Brotherhood Considered an Alliance Against Saudi Arabia." The Intercept, November 18, 2019. https://theinter cept.com/2019/11/18/iran-muslim-brotherhood-quds-force/.

Saad-Ghorayeb, Amal. Hizbu'llah: Politics and Religion. London: Pluto, 2002.

Sankari, Jamal. Fadlallah: The Making of a Radical Shi'ite Leader. London: Saqi Books, 2005.

Scheit, Gerhard. "Der neue Vernichtungswahn und seine internationalen Voraussetzungen: Wodurch sich Ahmadinejads Islamische Republik von Hitlerdeutschland unterscheidet.” In Der Iran: Analyse einer islamischen Diktatur und ihrer europäischen Förderer, edited by Stephan Grigat and Simone Dinah Hartmann, 58-78. Innsbruck: Studienverlag, 2008. 
Schiedel, Heribert. "Heiliger Hass. Zur rechtsextrem-iranischen Freundschaft." In Iran im Weltsystem: Bündnisse des Regimes und Perspektiven der Freiheitsbewegung, edited by Stephan Grigat and Simone Dinah Hartmann, 165-73. Innsbruck: Studienverlag, 2010.

Schweizer, Gerhard. Iran verstehen: Geschichte, Gesellschaft und Religion. Stuttgart: Klett-Cotta, 2017.

Shehada, Muhammad. "Iran Is Declaring War on Israel-From Gaza." Haaretz, May 29, 2019. https://www.haaretz.com/middle-east-news/.premium-iran-is-declaring-war-on-israelfrom-gaza-1.7065348.

Taylor, Adam. “The History of 'Death to America'." Washington Post, February 18, 2015. https://www.washingtonpost.com/news/worldviews/wp/2015/02/18/the-history-ofdeath-to-america/?utm_term=.0937e5ff77d7.

Ünal, Yusuf. "Sayyid Qutb in Iran: Translating the Islamist Ideologue in the Islamic Republic." Journal of Islamic and Muslim Studies 1, no. 2 (2016): 35-60.

Webman, Esther. "Die Rhetorik der Hisbollah: die Weiterführung eines antisemitischen Diskurses." Jahrbuch für Antisemitismusforschung 12 (2003): 39-55.

Weinstock, Nathan. Der zerrissene Faden: Wie die arabische Welt ihre Juden verlor, 1947-1967. Freiburg: ça ira, 2019.

Will, Alexander. "Iran-Besuch von Stephan Weil. Herzlicher Empfang mit abruptem Ende." NWZ Online, April 18, 2016. http://mobil.nwzonline.de/politik/niedersachsen/herzlicherempfang-mit-abruptem-ende_a_6,1,2390575300.html.

Wistrich, Robert S. A Lethal Obsession. Anti-Semitism from Antiquity to the Global Jihad. New York: Random House, 2010. 